\title{
Extensive authigenic quartz overgrowths in the gas- bearing Haynesville-Bossier Shale, USA
}

DOI:

10.1016/j.sedgeo.2017.05.001

Document Version

Accepted author manuscript

Link to publication record in Manchester Research Explorer

\section{Citation for published version (APA):}

Dowey, P., \& Taylor, K. (2017). Extensive authigenic quartz overgrowths in the gas-bearing Haynesville-Bossier Shale, USA. Sedimentary Geology. https://doi.org/10.1016/j.sedgeo.2017.05.001

\section{Published in:}

Sedimentary Geology

\section{Citing this paper}

Please note that where the full-text provided on Manchester Research Explorer is the Author Accepted Manuscript or Proof version this may differ from the final Published version. If citing, it is advised that you check and use the publisher's definitive version.

\section{General rights}

Copyright and moral rights for the publications made accessible in the Research Explorer are retained by the authors and/or other copyright owners and it is a condition of accessing publications that users recognise and abide by the legal requirements associated with these rights.

\section{Takedown policy}

If you believe that this document breaches copyright please refer to the University of Manchester's Takedown Procedures [http://man.ac.uk/04Y6Bo] or contact uml.scholarlycommunications@manchester.ac.uk providing relevant details, so we can investigate your claim.

\section{OPEN ACCESS}




\section{Accepted Manuscript}

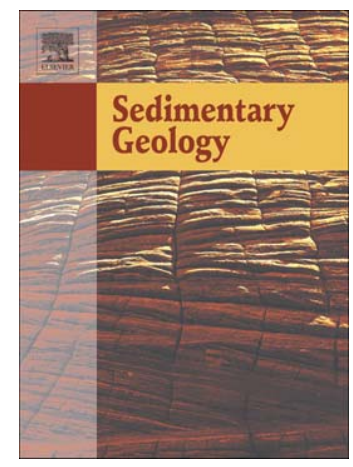

Extensive authigenic quartz overgrowths in the gas-bearing HaynesvilleBossier Shale, USA

Patrick J. Dowey, Kevin G. Taylor

PII:

S0037-0738(17)30110-0

DOI: $\quad$ doi: $10.1016 / j . s e d g e o .2017 .05 .001$

Reference: $\quad$ SEDGEO 5192

To appear in: $\quad$ Sedimentary Geology

Received date: 16 January 2017

Revised date: 2 May 2017

Accepted date: $\quad 9$ May 2017

Please cite this article as: Dowey, Patrick J., Taylor, Kevin G., Extensive authigenic quartz overgrowths in the gas-bearing Haynesville-Bossier Shale, USA, Sedimentary Geology (2017), doi:10.1016/j.sedgeo.2017.05.001

This is a PDF file of an unedited manuscript that has been accepted for publication. As a service to our customers we are providing this early version of the manuscript. The manuscript will undergo copyediting, typesetting, and review of the resulting proof before it is published in its final form. Please note that during the production process errors may be discovered which could affect the content, and all legal disclaimers that apply to the journal pertain. 


\title{
Extensive authigenic quartz overgrowths in the gas-bearing Haynesville-Bossier Shale, USA
}

\author{
Dowey, Patrick J.* \& Taylor, Kevin G. \\ School of Earth and Environmental Sciences, University of Manchester, M13 9WJ \\ Manchester, UK \\ ${ }^{*}$ Corresponding author
}

\begin{abstract}
In sandstone reservoirs, despite grain rearrangement during compaction, significant pore volumes may be retained prior to the onset of late diagenetic quartz cementation. In mudstone reservoirs, grain rearrangement during compaction results in significant pore volume reduction prior to late diagenesis. Where quartz overgrowths have been previously reported in post-compaction mudstones they have been in volumetrically low concentrations and interpreted as anomalous occurrences. Quartz cementation alters rock brittleness resulting in changes to mechanical fracture properties. Quartz overgrowths reduce reservoir porosity and permeability.
\end{abstract}

We present petrographic evidence of two phases of quartz cement in the HaynesvilleBossier Shale: (i) grain replacive and (ii) quartz overgrowths. Carbonate grain replacement is volumetrically low (<1\%). Quartz overgrowths identified from SEM-CL imaging are volumetrically more significant (8-13\%). Quartz overgrowths were most commonly observed in the coarse mudstone microfacies, but are present in both medium and fine mudstone microfacies. 
Petrographic evidence indicates three processes in the development of quartz overgrowths. Mica and pyrite are (i) engulfed and (ii) displaced by quartz overgrowth cement. The absence of a supportive, primary granular framework surrounding engulfed detrital and early authigenic minerals would indicate that quartz overgrowths are also replacive. Pressure dissolution of quartz silt grains and smectite-to-illite transformation are likely sources of silica for quartz cement. This study is the first to document large-scale, replacive, authigenic quartz overgrowth development within a producing mudstone.

Keywords: quartz cementation; quartz overgrowth; mudstone; diagenesis; Haynesville; Bossier;

\section{Introduction}

Quartz is a common mineral within mudstones (Blatt \& Schultz, 1976; Potter et al., 2005). It occurs both as a detrital component (either of intrabasinal or extrabasinal origin; Milliken, 2014) and as an authigenic mineral within various types of mudstone (Keene and Kastner, 1974; Day-Stirrat et al., 2010; Milliken et al., 2012, 2016). Bulk quartz composition has a significant control on rock brittleness affecting mechanical fracture properties of shale reservoirs. The textural characteristics of quartz also play a role in the behaviour of rocks during fracturing (Thyberg et al., 2010; Milliken et al., 2016).

Authigenic quartz cementation in mudstones has been identified previously (Isaacs 1982; Schieber et al. 2000). Schieber et al. (2000) described in situ quartz silt within Devonian mudstones sourced from the dissolution of opaline skeletons of planktonic organisms. This demonstrated that a significant proportion of the quartz silt within some mudstones may be authigenic and derived from biological sources. Milliken et al. (2016) recently described 
authigenic quartz cements infilling primary intragranular pores and replacing allochem grains in the Eagle Ford Formation. Silica was reported to be sourced from the dissolution of radiolarian skeletons.

Commonly, during late diagenesis in sandstones, abiotic sources can supply silica for authigenic quartz overgrowths on detrital quartz grains (Worden \& Burley 2003). Quartz overgrowths on detrital grains in mudstones are rarely reported, with quartz crystal growth interpreted to be limited by small pore volumes (Day-Stirrat et al. 2010). However, microscale $(<10 \mu \mathrm{m})$ authigenic quartz cements within low porosity mudstones do occur. Within the Late Cretaceous mudstones in the northern North Sea and the Norwegian Sea, sheet-like microscale quartz has been reported (Peltonen et al. 2009; Thyberg et al. 2010; Thyberg \& Jahren 2011). These examples are distinct from early diagenetic microcrystalline quartz observed in reservoir sandstones which forms through opaline (amorphous) forms ( Vagle et al. 1994; Worden et al. 2012; French \& Worden 2013). Silica for quartz cement in the Cretaceous examples above is interpreted to have resulted from clay mineral transformations at temperatures exceeding $90^{\circ} \mathrm{C}$ (Thyberg \& Jahren 2011). Evidence for the role of clay mineral transformations in authigenic quartz formation is further supported by laboratory experiments (Metwally \& Chesnokov 2012).

Day-Stirrat et al. (2010) reported on detrital and authigenic quartz in Wilcox Group mudstones. The authors identified rare 'zones' of macroscale ( $>10 \mu \mathrm{m})$, authigenic quartz cement on detrital quartz silt grains. However, except for a few rare examples, the silicadominated Wilcox Group was interpreted to lack widespread authigenic quartz overgrowth development. 
In spite of the rare occurrences of macroscale quartz overgrowths, the extensive evidence for microscale quartz overgrowth indicates that silica mobility and quartz cementation are processes which occur in mudstones. Further case studies and examples of authigenic quartz development will enable silica mobility on reservoir and basin scales to be better understood (Day-Stirrat et al. 2010) and the how mechanical fracture properties are affected (Thyberg et al. 2010). The Haynesville-Bossier Shale contains both clay mineral- and detrital quartz-rich microfacies and is thermally gas mature (Buller \& Dix 2009; Hammes 2009; Spain \& Anderson 2010; Wang et al. 2013). It therefore provides a good opportunity to study authigenic quartz cementation. The study seeks to address the following research questions:

1 How extensive is quartz cementation?

2 What processes play a role in quartz cementation?

3 What are the potential sources of silica?

4 How does quartz cementation impact reservoir properties?

\section{Geology}

Collectively the Kimmeridgian to Berrasian Haynesville and Bossier Shales supplies over eight percent of the total US shale gas production (EIA, 2016). Although production has focused on the Haynesville, there has been increasing interest in the Bossier in recent years (EIA, 2011). During the Early Jurassic, rifting along the proto-Atlantic margin generated a series of positive and negative features across a region of the present day Gulf of Mexico. Positive features formed a series of shallow blocks; negative features formed deep submerged basins (Adams 2009; Ewing 2009; Hammes et al. 2011). These basins include the 
East Texas and the North Louisiana Basins where the Haynesville and Bossier Shales were deposited (Ewing, 1991; Sawyer et al., 1991; Hammes et al., 2011).

The background to the paleogeography, chronostratigraphy and burial history of the studied Haynesville-Bossier cores is outlined in figure1. The Haynesville and Bossier Shales comprise the upper portion of a transgressive systems tract and the entirety of a highstand systems tract, respectively (Fig. 1A, Hammes 2009; Cicero et al. 2010). Sediment supply controlled the composition of the two shales. The Lower Haynesville Shale is a thick carbonate-bearing, organic-rich shale, deposited in the deepest parts of the basin during a period of low siliciclastic sediment supply (Fig. 1B). Increasing terrestrial sediment supply from northern river systems and marine transgressions towards the end of the Kimmeridgian resulted in an expanding area of shale deposition and dilution of organic matter concentrations during the Upper Haynesville. The switch from the carbonate-dominated Haynesville system to a siliciclastic-dominated Bossier system is marked by maximum flooding surface (Cicero et al. 2010). During the Tithonian (Bossier deposition) increasingly large volumes of terrestrial sediment from northern river systems began to encroach in to the basin, resulting in further widening of shale deposition and further organic matter dilution (Ewing, 2001, 2009; Klein and Chaivre, 2002; Martin and Ewing, 2009; Cicero et al., 2010).

Continued sediment supply during the early Cretaceous resulted in rapid burial (Ewing, 2001, 2009; Fig. 1C). The Haynesville-Bossier reached a maximum burial depth in the range of 2,900-3,500 m (Williams 2013) by approximately 100 Ma. Basin modelling (Torsch, 2012) indicates that the centre of the basin entered the oil window at approximately $1200 \mathrm{~m}$ around $140-130 \mathrm{Ma}$, before later entering the dry gas window at $3400 \mathrm{~m}$ around $110-100$ Ma. Subsequently, during the middle Cretaceous to Eocene, there were a series of uplift events in the region. the South Arkansas Uplift (100-95 Ma) was the largest phase (up to 
$3,000 \mathrm{~m}$ ) in some northern areas (Ewing 2009). The Haynesville shale is presently at a burial depth ranging between $3000 \mathrm{~m}$ and $5500 \mathrm{~m}$ (Wang et al. 2013)

\section{Methods}

Samples in this study were collected from three cores: Brazell 18 No.10, Hewitt land LLC4-1, and Jarvis East No.1, and are referred to in the remainder of the text as $\mathrm{HA}, \mathrm{HB}$, and $\mathrm{HC}$ respectively. The cores have a combined thickness of $350 \mathrm{~m}$ in the Haynesville-Bossier sequence of Western Louisiana and Eastern Texas. The wells were cover shallow marginal and deep basinal areas of the both the Haynesville and Bossier Shale play (Fig. 1A). The three cores are from similar present day depths of $\sim 3400-3750 \mathrm{~m}$. Proprietary vitrinite reflectance and well temperature data indicate that the deepest section of each core are well within the dry gas zone ( $>2 \%$ Ro), and current temperatures range between $140{ }^{\circ} \mathrm{C}$ and $154^{\circ} \mathrm{C}$. Sixty-three samples from the three cores were collected to encompass the observed variability and provide a wide stratigraphic spread. High quality polished extra-thin thin sections $(<20 \mu \mathrm{m})$ were prepared for each sample.

Quartz cements and microfacies were analysed using extra-thin thin sections under optical plane-polarised and cross-polarised light using a Nikon Eclipse LV100N POL microscope at the University of Manchester. High resolution BSE images for quantitative grain size measurements were collected using a FEI XL30 ESEM using a EDAX Gemini EDS and a FEI Quanta 650 FEG SEM at the University of Manchester. Quantitative grain size measurement of grain long axes were undertaken using the BSE SEM image maps utilising the point-count and 2D measurement applications in J-Microvision software (Roduit 2008). 200 points per sample were counted. Grain sizes for the samples were calculated using (Blott 2008). 
SEM-cathodoluminesence (SEM-CL) images were collected using both a Philips XL30 tungsten filament SEM with a K.E. Developments (Centaurus) SEM CL and BSE detector at the University of Liverpool and a JEOL JXA-8530F Hyperprobe equipped with a JEOL panchromatic cathodoluminescence detector at the University of Manchester. Quantitative measurement of the extent of quartz cementation was collected with BSE, SEM-CL and elemental silica images utilising the point-counting application in J-Microvision software (Roduit 2008). 300 points per sample were counted.

Total organic carbon was analysed at the University of Newcastle using a Leco CS230 carbon analyser. Inorganic carbon was first removed using hydrochloric acid (5M), followed by rinsing with distilled water. Dried samples were then heated in an oxygen atmosphere within the furnace $\left(\sim 1500^{\circ} \mathrm{C}\right)$ of the carbon analyser. $\mathrm{CO}_{2}$ was measured using an infrared detector. Measurements are calibrated using carbon standards; replicate and blank analyses were also carried out.

Proprietary whole sample XRD data were kindly supplied by Shell (formerly BG Group). Confirmation of the clay minerals present was completed on grain separates from an individual sample from the HB core (Bossier). Standard sample preparation procedures for clay and silt-size fraction and glycolation were undertaken (Moore \& Reynolds 1997). Size separation was performed by disaggregation of half-core plug in a tungsten disc mill, followed by ultrasonication, sieving, gravity settling, and centrifugation. Further crushing was performed using agate ball mill, followed by drying at $60^{\circ} \mathrm{C}$ and glycolation at $60{ }^{\circ} \mathrm{C}$ and vapour pressure. Samples were scanned as randomly-orientated powders using a PANalytical X'Pert PRO diffractometer (Cu k- $\alpha$ source) at the University of Liverpool, with quantification by RIR semi-Quant in HighScore software. 
Major and trace element analyses were carried out on forty-two samples using a PANalytical Axios sequential X-ray fluorescence spectrometer at the University of Manchester. Sample preparation involved grinding $12 \mathrm{~g}$ of sample then adding $3 \mathrm{~g}$ of additive, the sample is then pressed to form a pellet. Concentrations below the lower limit of detection were removed.

\section{Microfacies}

Facies and microfacies are outlined here to demonstrate that quartz cementation is not limited to quartz silt-rich sections of the studied cores. Following the classification of Lazar et al. (2015), at the thin section scale four microfacies are present. Representative images of these microfacies fine mudstone ( $\mathrm{fMs}$ ), medium mudstone (mMs), coarse mudstone (cMs) and sandy mudstone (sMs) are presented in Figure 2A-D. Long axes grain size measurements from nine representative samples (fig 2 E \& F) demonstrate that samples fall in to these grain size classes. Within all three cores $\mathrm{mMs}$ is the most common microfacies (Fig. 2B). fMs is generally rare with only a few samples containing greater than two-thirds grains of fine mud size (Fig. 2A). cMs and sMs (Fig. 2C \& D) form the upper section of coarsening upwards packages in the HB (33 m thick) and HC cores (143 m thick).

\section{Detrital minerals}

Fine-grained detrital components $(<62.5 \mu \mathrm{m})$ include quartz and carbonate allochems, but are dominated by clay minerals. Proprietary, whole sample XRD data from both the Haynesville and Bossier Shales indicates the presence of illite, quartz, calcite, plagioclase feldspar, chlorite, dolomite, pyrite, apatite, potassium feldspar, kaolinite and mixed layer illite/smectite. (Table 1). Although the mineral concentrations vary between the two formations, they contain the same assemblage. Carbonates are more dominant in the 
Haynesville Formation and siliciclastics are more dominant in the Bossier Formation (Cicero et al. 2010; Hammes 2009). XRD analysis of fine powders $(<2 \mu \mathrm{m})$ confirms the presence of both illite and illite-smectite (Fig. 3). The illite-smectite is composed of $10 \%$ smectite interstratified with 90 \% illite (Moore \& Reynolds, 1997). Illite is present in high concentrations. Given the maximum burial depth experienced by the Haynesville-Bossier Shales the original detrital phase is assumed here to have been smectite.

Granular components vary both between and within the studied cores. Silt-size components include detrital quartz grains, micas and carbonate allochems which can range up to sand size. Carbonate allochems include pellets, gastropods, bivalves, ostracods, coccolith fragments and undefined shelly debris. Organic matter is present throughout most of the cores and varies between 0.15 and $2.71 \mathrm{wt} \%$, with a mean of $1.38 \mathrm{wt} \%$ (s.e. $0.72 \mathrm{wt} \%$ ). Amorphous organic matter $(1-50 \mu \mathrm{m})$ and inertite $(50-100 \mu \mathrm{m})$ were both observed.

Detrital quartz is common throughout the studied samples, particularly in the HB and HC samples. The concentration of detrital quartz varies within the cores, but is higher in the cMs and sMs microfacies where it forms the majority of the silt and sand size grains (fig. 2). Detrital quartz grains range in size from $10-60 \mu \mathrm{m}$ and are sub-rounded to angular in shape.

\section{Authigenic quartz}

\subsection{Grain replacive quartz}

Authigenic, subhedral to euhedral quartz partially replaces recrystallised calcite in carbonate allochems (Fig. 4). Carbonate bioclast replacement is commonly by small euhedral crystals $(<10 \mu \mathrm{m})$ of quartz cement (Fig. $4 \mathrm{~A})$. Rarely up to $80 \%$ of the original carbonate mineral is 
replaced by quartz (Fig. 4B). Within the carbonate bioclasts, pyrite, albite and dolomite replacive cements occur alongside the quartz cement (Fig. 4C). Carbonate-recrystallisation makes identification of the original bioclasts difficult (Fig. 4C), but they commonly appear to be gastropods (Fig. 4A \& B). Other carbonate allochems such as bivalves also appear to have been partially replaced (Fig. 4D).

\subsection{Quartz cement}

Quartz cement is present throughout the Haynesville-Bossier samples. In the coarse mudstone (cMs) and sandy mudstone (sMs) microfacies, numerous silt grain contacts are evident in BSE images (Fig. 5). Initially these features appear to be classic pressure solution features where grain-on-grain contacts result from compaction (Rutter, 1983; Alcantar et al., 2003). However, more detailed study demonstrates two common features of the grains within the cMs and sMs: the presence of delicate quartz grain textures (Fig. 6A) and small grains of pyrite and mica ( $100-2000 \mathrm{~nm}$ ) at the interface of quartz silt grains (Fig. 6 B-D). The delicate quartz grain textures are thin and elongate with a 'bulbous' morphology (Fig. $6 \mathrm{~A})$. Contacts between the quartz silt have thin discontinuities $(<100 \mathrm{~nm}$ wide) between the grain surfaces. In the fine mudstone (fMs) and medium mudstone (mMs) microfacies, where silt grain contacts are less common, quartz cement is still present, as indicated by trapped mica (Fig. 6E) and discontinuities in quartz grains (Fig. 6F).

SEM-CL imaging (Fig. 7 A, C, E \& F) shows the presence of dull luminescence quartz cement at the periphery of high luminescence detrital quartz grains. Euhedral cement surfaces are sometimes present (Fig. 7C \& D), but commonly cement surfaces have 'bulbous' projections in to the adjacent clay mineral-rich matrix (Fig. 7A, B, E \& F). The cements are common in the cMs and sMs microfacies (Fig. $7 \mathrm{~A}-\mathrm{F}$ ) but are still observed in the $\mathrm{fMs}$ and $\mathrm{mMs}$ 
microfacies (Fig. $7 \mathrm{G} \mathrm{\&} \mathrm{H).} \mathrm{In} \mathrm{the} \mathrm{cMs} \mathrm{and} \mathrm{sMs} \mathrm{microfacies,} \mathrm{apparent} \mathrm{quartz} \mathrm{overgrowths} \mathrm{are}$ commonly either intergrown with (Fig. 8A), or encased in (Fig. 8B) calcite and dolomite cements.

\subsection{Quantitative measurement}

Point-count data from two BSE, SEM-CL and silica element map datasets were collected from one cMS sample to give a quantitative estimate of the extent of authigenic quartz cementation observed. Authigenic quartz cementation was calculated to be between $8 \%$ and $13 \%$ by area in the two image dataset. This included both grain replacive and cement types of quartz, although the latter was the most evident in the measured image sets.

\subsection{XRF data}

Silica in mudstones can have are biotic of abiotic sources (Isaacs 1981; Isaacs 1982; Rice et al. 1995; Schieber et al. 2000; Milliken et al. 2016). Discrimination of these silica sources can be done using silica and zirconium plots. Correlation between these elements is thought to reflect the presence of zircon within the sediment and interpreted to be a proxy for a detrital source of silica (Calvert et al. 1996; Ross \& Bustin 2009; Smith \& Malicse 2010; Wright et al. 2010; Blood et al. 2013;). A negative correlation is interpreted to indicate a biogenic source for silica, this has been identified in Muskwa Formation which has a known biogenic silica source (Wright et al. 2010). Silica and zirconium data are plotted in Figure 9. The figure demonstrates a strong positive correlation coefficient between silica and zirconium with an $\mathrm{R}^{2}$ value of 0.72 . This suggests that silica and zirconium concentrations are related. 


\section{Discussion}

In the studied Haynesville-Bossier samples, two types of quartz cement are apparent: grainreplacing euhedral quartz and euhedral and anhedral quartz overgrowths. Carbonate bioclast-replaced by euhedral quartz (Fig. 4A) is a common feature in many mudstones (Milliken and Day-Stirrat, 2013; Milliken et al., 2016). However, quartz overgrowths on detrital grain surfaces (Fig. 6 \& 7) are not commonly observed in mudstones and have been considered to be volumetrically insignificant and therefore anomalous (Day-Stirrat et al. 2010). In the data presented here, quartz overgrowths are common and occupy a significant proportion of the studied thin sections (up to $13 \%$ of the area). The presence of relatively rarely reported quartz overgrowths in a mudstone has implications for how diagenesis in fine-grained sediments is understood.

\subsection{Quartz overgrowth texture}

In a study of Wilcox Group mudstones, Day-Stirrat et al. (2010), identified several reasons why 'quartz zones' similar to overgrowths reported here, were unlikely to be in situ authigenic quartz overgrowths. It is useful to discuss the observed overgrowths in the Haynesville-Bossier Shale in context of the issues identified by Day-Stirrat et al. (2010).

(1) Quartz overgrowths in sandstones do not have a variable SEM-CL response. While there is some slight variability in SEM-CL response of some quartz cement identified in this study (Fig. $7 \mathrm{~A} \& \mathrm{C}$ ), the quartz cement appears to have a broadly consistent $\mathrm{CL}$ response even between different samples (Fig. 7 C\&D) The slight variability could indicate subtle variations in fluid composition during mineral precipitation (Turner et al. 1995) or that there were multiple independent phases of cementation, a feature which is commonly observed in 
some sandstones using SEM (Lyon et al., 2000; Spötl et al., 2000; Friis et al., 2010) rather than SEM-CL imaging.

(2) Quartz overgrowths are present on a small minority of grains. This is not the case in the studied Haynesville-Bossier samples, where the volume of quartz overgrowths could be related to the proportion of detrital silt present. Heavily cemented samples with greater detrital silt content (Fig. 7 A-F) have significantly greater surface areas available for cementation (Day-Stirrat et al. 2010). Quantification on a small subset (two) of the samples using point-counting indicates the potential scale of quartz cementation within the cMs and sMs microfacies.

(3) Quartz overgrowths tend to have euhedral morphologies. In the Wilcox Group, anhedral and abraded grain boundaries were interpreted to result from sediment transport rather than quartz overgrowth development (Day-Stirrat et al. 2010). Some Haynesville-Bossier samples do have euhedral grain boundaries, but the majority are anhedral. Some of these anhedral quartz cement boundaries have bulbous projections (Fig. 6A \& 7D). A bulbous morphology could be interpreted as rounding; however delicate morphologies would be unlikely to survive sediment transport and so these features are interpreted to be authigenic rather than detrital. The value of euhedral textures as an indicator for quartz overgrowths in mudstones may also have limited value. As a developing quartz crystal grows it will grow until it fills the adjacent available pore volume. With a sufficient supply of silica, the shape of the pore in to which the quartz crystal grows will define the shape of the crystal. In mudstones where pore volumes are small and shapes are generally irregular, this will produce anhedral quartz overgrowths. This is similar to anhedral quartz overgrowths which develop beneath the surface of clay mineral grain coats in sandstone reservoirs. The 
quartz crystal is limited by the composition and completeness of coats (Ajdukiewicz \& Larese, 2012).

Although the quartz cement has a slight variation in SEM-CL response, the scale of the cement and the euhedral and bulbous projections of a majority of the observed grains would suggest that the quartz cement forming on detrital quartz grain surfaces be interpreted as quartz overgrowths.

(4) The final issue identified by Day-Stirrat et al. (2010) is insufficient pore space for quartz cement to grow. Pore volumes decrease significantly with burial due to compaction (Dewhurst et al., 1998), while quartz cementation is related to temperature and is normally a late diagenetic feature, particularly in sandstones (Worden \& Morad, 2000). Day-Stirrat et al. (2010) identified small quartz overgrowths which were interpreted to have developed in 'clay mineral-free pockets', but there is no evidence for this in the studied HaynesvilleBossier samples. Quartz cement in mudstones can occur early in diagenesis due to the dissolution of amorphous detrital sponge spicules (Aase et al., 1996; Schieber et al., 2000; Milliken et al., 2016). However, sponge spicules are absent in the studied samples and silica and zirconium concentrations in the XRF geochemical data (Fig. 9) have a positive correlation. A positive correlation indicate that the silica is sourced from a detrital (Wright et al. 2010) rather than biogenic sources (a biogenic source would have a negative correlation). The data does not support the interpretation that quartz is an early diagenetic cement.

Quartz overgrowths may either engulf, displace, or replace adjacent matrix components (Day-Stirrat et al. 2010). In the Haynesville-Bossier samples, quartz overgrowths engulf mica and pyrite matrix components (Fig. 6). Displacement of matrix components also occurred 
during cementation as indicated by the alignment of mica and pyrite perpendicular to the interfaces between quartz silt grains (Fig. 6 B-D). The presence of matrix components engulfed by quartz overgrowth cement raises an important question- how do isolated matrix components within the quartz overgrowth come to be engulfed? Isolated detrital and early diagenetic cements would have been supported by a primary detrital framework prior to quartz cement formation. Observed quartz overgrowths could not therefore have developed in to clay mineral free pockets, but would replace primary detrital framework. These observations suggest that quartz overgrowth development involved elements of engulfment, displacement and replacement (Fig. 10).

As suggested by Day-Stirrat et al. (2010), force of crystallization replacement (Maliva \& Siever, 1988) is a potential process whereby replacement of detrital framework components could occur. Force of crystallisation replacement occurs where crystal growth within a supersaturated fluid applies pressure to surrounding components. Pressure applied at the interface between the crystal and the component increases Gibbs free energy and therefore solubility at the contact with the component; where the component is soluble it dissolves (Maliva \& Siever, 1988). Where this occurs, the presence of a thin nanometre scale solution film is predicted (Weyl, 1959; Maliva and Siever, 1988; Fig. 10). The small discontinuity observed between grains (Fig. 6B-D \& F) could represent a solution film.

\subsection{Silica sources}

The sources of quartz cementation in sandstones are considered to be well understood and all may be possible sources of silica in mudstones. Common silica sources include (Worden \& Morad, 2000): (1) external sources such as intrusions or mudstones (2) detrital potassium 
feldspar, (3) dissolution of amorphous silica, (4) pressure dissolution and (5)

illitisation/chloritisation of smectite.

An external supply of silica (1) for the Haynesville-Bossier is unlikely due to low permeabilities and high formation pressures. High fluid flux is also required for sufficient quartz cementation (Bjørlykke, 1994, 2011) and a possible external silica source has not been identified. Silica can also be sourced from potassium feldspar dissolution (2). However, potassium feldspar concentrations are low in the studied samples and there appears to be no evidence of dissolution or replacement of potassium feldspars.

Dissolution of biogenic amorphous silica (3) in mudstones has been demonstrated to form authigenic quartz through the dissolution of opal-A, with silica recrystallizing as quartz via opal-CT (Isaacs, 1981, 1982; Rice et al., 1995; Milliken et al., 2016). Correlation between silica and zirconium in mudstones reflects the presence of zircon within the sediment and is interpreted to be a proxy for a detrital source of silica (Calvert et al. 1996; Ross \& Bustin 2009; Smith \& Malicse 2010; Wright et al. 2010; Blood et al. 2013). The correlation between zirconium and $\mathrm{SiO}_{2}$ concentrations in this study (Fig. 9) and a previous study (Wright et al. 2010), indicate that the silica within the Haynesville-Bossier Shale was an abiotic detrital mineral phase.

Quartz overgrowths are present in most samples studied, but are more common in the cMs and sMs microfacies. Images of detrital grain contacts associated with quartz overgrowths (Fig. 5) indicate that pressure solution (4) is one mechanism producing silica for quartz overgrowths within the cMs and sMs microfacies. In the mMs and fMs microfacies, quartz overgrowth were present, but pressure solution is less likely to be a factor because of the low concentration of rigid grains results in few grain-grain contacts. Pressure solution can 
occur at quartz-mica grain contacts (Bjorkum 1996), but inter-penetrating clay mineralquartz textures were not observed in silt-poor microfacies in the present study. Overburden strain was probably accommodated by the deformation of surrounding ductile clay mineraland organic matter-rich detrital framework within the fMs microfacies.

Silica is released during smectite transformation (5), either through the illitisation or chloritisation of smectite (Boles and Franks, 1979; Hillier, 1994; Weibel, 1999; Dowey et al., 2012). XRD analysis demonstrated that smectite has partially undergone transformation to illite (Fig. 3). High concentrations of illite within the studied samples suggest that smectite transformation is likely to have made a significant contribution to silica concentrations alongside pressure solution in silt-rich samples.

Micro-quartz development within the matrix of mudstones has been interpreted to develop during late diagenesis from the illitisation of smectite or the illitisation of kaolinite (Peltonen et al. 2009; Thyberg et al. 2010; Thyberg \& Jahren 2011). This is further supported by evidence of quartz precipitation from clay mineral transformation laboratory experiments (Metwally \& Chesnokov, 2012). The high concentration of clay minerals in some mudstone reservoirs (Wilson et al., 2016) indicates that clay mineral transformations may release large volumes of silica in to formation pore waters.

Petrographic and geochemical data indicate that two processes are likely to supply silica for quartz cementation. Pressure solution in the cMs and sMs microfacies is likely to be important where silt grains are in contact. In the $\mathrm{mMs}$ and $\mathrm{fMs}$ microfacies, where grain contacts are less common, a smectite to illite transformation producing an excess of silica is probably the dominant process. Although both pressure solution and clay mineral transformations may occur in all microfacies. 


\subsection{Implications}

Quartz overgrowths are present in Haynesville and Bossier Shale samples from three wells and three different microfacies. This indicates that quartz cementation, and more specifically quartz overgrowths, occur in mudstones on a reservoir scale. This is the first time that abiotically-derived quartz cementation on this scale has been recognised in a producing shale reservoir.

Quartz cementation has a major effect on rock structure in sandstone reservoirs (Worden \& Morad, 2000), by increasing rock brittleness and occupying pore space reducing porosity and effecting permeability. Quartz cement will have an impact on mudstone structure, due to commonly low porosity and permeability and the importance of rock brittleness during hydraulic fracturing. Brittleness is an important characteristic for shale reservoirs as it can improve fracture generation and propagation. The quartz cements observed, particularly those within the $\mathrm{cMs}$ and sMs microfacies form a grain-binding network of quartz grains and quartz cement (Milliken et al. 2016) which would be more susceptible to natural or induced fracturing than uncemented mudstones. The replacement of matrix components through quartz cementation, may also have a large impact on porosity and permeability, particularly where porosity is inter-granular, as in the Haynesville-Bossier (Loucks et al., 2010; Wang et al. 2013; Klaver et al., 2015). Replacement of this intergranular volume with quartz could, depending on the scale of the cement, significantly reduce porosity.

Quartz cementation during diagenesis in sandstones is thought to be well understood (Worden \& Morad 2000). However, quartz cementation in mudstone reservoirs is complex, with multiple processes that have different impacts on reservoir properties. Compaction and temperature-controlled clay mineral transformations could have a significant role in 
silica mobilisation in mudstones during diagenesis. Understanding how these processes affect silica mobility on a basin scale has important consequences for understanding of diagenesis in siliciclastic systems more widely.

\section{Conclusions}

1 Authigenic quartz cements are present in the Haynesville-Bossier Shale in two phases- (1) grain replacements and (2) grain overgrowths.

2 Grain-replacement of carbonate bioclasts is volumetrically rare.

3 Quartz cement is areally significant in the coarse mudstone microfacies (cMs and sMs) at up to $13 \%$. Quartz cement is also present in the medium (mMs) and fine (fMs) mudstone microfacies.

4 Mica and pyrite matrix components are engulfed and displaced by quartz cement. Quartz overgrowth textures appear to have replaced primary detrital framework.

5 Pressure dissolution at detrital quartz grain contacts and smectite-to-illite transformation are likely sources for silica during diagenesis. Temperature and the extent of compaction are important controls on silica diagenesis in these mudstones.

6 Quartz overgrowth cements affect rock brittleness and reduce porosity in mudstone reservoirs. The Identification of extensive silica mobility in mudstones furthers the understanding of basin scale element mobility.

\section{Acknowledgements}

Shell (formerly BG Group) is thanked for the supply of samples and permission to use the well names. Shell (formerly BG Group), Chevron and Schlumberger are gratefully acknowledged for their financial contributions to this research through the Mudstone and 
Shale Gas Research (MSGR) group. The authors acknowledge the support of the NERCfunded Nanoscale Imaging and Analysis Facility for Environmental Materials (NIAFEM) Facility in the Williamson Research Centre for Molecular Environmental Science, University of Manchester (NERC CCO42). James Utley at the University of Liverpool is thanked for XRD clay mineral analysis. Carmel Pinnington of the University of Liverpool is thanked for her help with the SEM-CL. Jonathon Fellowes and Heath Bagshaw are thanked for their assistance with SEM and SEM-CL at the University of Manchester.

\section{References}

Aase, N.E., Bjørkum, P.A. \& Nadeau, P.H., 1996. The Effect of Grain-Coating Microquartz on Preservation of Reservoir Porosity. AAPG Bulletin 80 (10),1654-1673.

Adams, R.L., 2009. Basement Tectonics and Origin of the Sabine Uplift. Gulf Coast Association of Geological Sciences Transactions 59, 3-19.

Ajdukiewicz, J.M. \& Larese, R.E., 2012. How clay grain coats inhibit quartz cement and preserve porosity in deeply buried sandstones: Observations and experiments. AAPG Bulletin 96 (11), 2091-2119.

Alcantar, N., Israelachvili, J. \& Boles, J., 2003. Forces and ionic transport between mica surfaces: implications for pressure solution. Geochimica et Cosmochimica Acta 67 (7), 1289-1304.

Bjorkum, P.A., 1996. How important is pressure in causing dissolution of quartz in sandstones? Journal of Sedimentary Research 66 (1), 147-154.

Bjørlykke, K., 2011. Open-system chemical behaviour of Wilcox Group mudstones. How is large scale mass transfer at great burial depth in sedimentary basins possible? A discussion. Marine and Petroleum Geology, 28(7), 1381-1382. 
Bjørlykke, K., 1994. Pore water flow and mass transfer of solids in solution in sedimenary

basins. In A. Parker \& B. W. Sellwood, eds. Quantitative diagenesis: Recent

developments and applications to reservoir geology. Dordrecht: Kluwer, 189-221.

Blatt, H. \& Schultz, D.J., 1976. Size distribution of quartz in mudrocks. Sedimentology 23 (6), 857-866.

Blood, R., Lash, G. \& Bridges, L., 2013. Biogenic Silica in the Devonian Shale Succession of the Appalachian Basin, USA. In AAPG Search and Discovery Article.

Blott, S.J., 2008. Gradistat V. 7. Available at: http://www.kpal.co.uk/gradistat_abstract.htm.

Boles, J.R. \& Franks, S.G., 1979. Clay diagenesis in Wilcox sandstones of southwest Texas: Implications of smectite diagenesis on sandstone cementation. Journal of Sedimentary Petrology 49 (1), 55-70.

Buller, D. \& Dix, M.C., 2009. Petrophysical Evaluation of the Haynesville Shale in Northwest Louisiana and Northeast Texas. Gulf Coast Association of Geological Societies Transactions 59, 127-143.

Calvert, S.E., Bustin, R.M. \& Ingall, E.D., 1996. Influence of water column anoxia and sediment supply on the burial and preservation of organic carbon in marine shales. Geochimica et Cosmochimica Acta 60 (9), 1577-1593.

Cicero, A.D. et al., 2010. Sequence Stratigraphy of the Upper Jurassic Mixed Carbonate/Siliciclastic Haynesville and Bossier Shale Depositional Systems in East Texas and North Louisiana. Gulf Coast Association of Geological Societies Transactions 60, 133-148.

Day-Stirrat, R.J. et al., 2010. Open-system chemical behavior in deep Wilcox Group mudstones, Texas Gulf Coast, USA. Marine and Petroleum Geology 27 (9), 1804-1818. Dewhurst, D.N. et al., 1998. Compaction-driven evolution of porosity and permeability in 
natural mudstones: An experimental study. Journal of Geophysical Research 103 (B1), 651.

Dowey, P.J., Hodgson, D.M. \& Worden, R.H., 2012. Pre-requisites, processes, and prediction of chlorite grain coatings in petroleum reservoirs: A review of subsurface examples. Marine and Petroleum Geology 32 (1), 63-75.

EIA, 2011. Haynesville-Bossier Shale Play, Texas-Louisiana Salt Basin. Available at: http://www.eia.gov/oil_gas/rpd/shaleusa4.pdf [Accessed September 20, 2016].

EIA, 2016. Natural Gas Weekly Update. Available at: http://www.eia.gov/naturalgas/weekly/ [Accessed August 19, 2016].

Ewing, T.E., 2001. Review of Late Jurassic Depositional Systems and Potential Hydrocarbon Plays, Northern Gulf of Mexico Basin. Gulf Coast Association of Geological Societies Transactions LI, 85-96.

Ewing, T.E., 1991. Structural features. In A. Salvador, ed. The Gulf of Mexico Basin. Geological Society of America, Geology of North America, 31-52.

Ewing, T.E., 2009. The Ups and Downs of the Sabine Uplift and the Northern Gulf of Mexico Basin: Jurassic Basement Blocks, Cretaceous Thermal Uplifts, and Cenozoic Flexure. Gulf Coast Association of Geological Societies Transactions 59, 253-269.

French, M.W. \& Worden, R.H., 2013. Orientation of microcrystalline quartz in the Fontainebleau Formation, Paris Basin and why it preserves porosity. Sedimentary Geology 284-285, 149-158.

Friis, H. et al., 2010. Hydrothermally influenced cementation of sandstone - An example from deeply buried Cambrian sandstones from Bornholm, Denmark. Sedimentary Geology 227 (1-4), 11-19.

Hammes, U., 2009. Sequence stratigraphy and core facies of the Haynesville Mudstone, East 
Texas. Gulf Coast Association of Geological Societies Transactions 59, 321-324.

Hammes, U., Hamlin, H.S. \& Ewing, T.E., 2011. Geologic analysis of the Upper Jurassic Haynesville Shale in east Texas and west Louisiana. AAPG Bulletin 95 (10), 1643-1666. Hillier, S., 1994. Pore-lining chlorites in siliclastic reservoir sandstones; electron microprobe, SEM and XRD data, and implications for their origin. Clay Minerals 29, 665-679. Isaacs, C.M., 1982. Influence of rock composition on kinetics of silica phase changes in the Monterey Formation, Santa Barbara area, California. Geology 10 (6), 304-308.

Isaacs, C.M., 1981. Porosity reduction during diagenesis of the Monterey formation, Santa Barbara coastal area, California. In R. E. Garrison \& R. G. Douglas, eds. The Monterey Formation and related siliceous rocks of California. Special Publication Pacific Section of the SEPM, 257-271.

Keene, J.B. \& Kastner, M., 1974. Clays and formation of deep-sea chert. Nature 249 (5459), $754-755$.

Klaver, J. et al., 2015. BIB-SEM characterization of pore space morphology and distribution in postmature to overmature samples from the Haynesville and Bossier Shales. Marine and Petroleum Geology 59, 451-466.

Klein, G.D. \& Chaivre, K.R., 2002. Sequence and Seismic Stratigraphy of the Bossier Formation (Tithonian), Western East Texas Basin. Gulf Coast Association of Geological Societies Transactions 52, 551-561.

Lazar, O.R. et al., 2015. Capturing Key Attributes of Fine-Grained Sedimentary Rocks In Outcrops, Cores, and Thin Sections: Nomenclature and Description Guidelines. Journal of Sedimentary Research 85 (3), 230-246.

Loucks, R.G. et al., 2010. Preliminary Classification of Matrix Pores in Mudrocks. Gulf Coast Association of Geological Societies Transactions 60, 435-441. 
Lyon, I.C. et al., 2000. Oxygen isotope analysis of authigenic quartz in sandstones: A comparison of ion microprobe and conventional analytical techniques. In R. H. Worden \& S. Morad, eds. Quartz Cementation in Sandstones. International Association of Sedimentologists, 299-316.

Maliva, R.G. \& Siever, R., 1988. Diagenetic replacement controlled by force of crystallization. Geology 16(8), 688-691.

Martin, B.J. \& Ewing, T.E., 2009. Ancestral Basin Architecture: A Possible Key to the Jurassic Haynesville Trend. Gulf Coast Association of Geological Societies Transactions 59, 511515.

Metwally, Y.M. \& Chesnokov, E.M., 2012. Clay mineral transformation as a major source for authigenic quartz in thermo-mature gas shale. Applied Clay Science 55 (0), 138-150. Milliken, K.L., 2014. A compositional classification for grain assemblages in fine-grained sediments and sedimentary rocks. Journal of Sedimentary Research 84 (12), 11851199.

Milliken, K.L. et al., 2012. Grain assemblages and strong diagenetic overprinting in siliceous mudrocks, Barnett Shale (Mississippian), Fort Worth Basin, Texas. AAPG Bulletin 96 (8), $1553-1578$.

Milliken, K.L. \& Day-Stirrat, R.J., 2013. Cementation in mudrocks: Brief review with examples from cratonic basin mudrocks. In J. Chatellier \& D. Jarvie, eds. AAPG Memoir 103. 133150.

Milliken, K.L., Ergene, S.M. \& Ozkan, A., 2016. Quartz types, authigenic and detrital, in the Upper Cretaceous Eagle Ford Formation, South Texas, USA. Sedimentary Geology 319, 273-288.

Moore, D.M. \& Reynolds, R.C., 1997. X-Ray Diffraction and the Identification and Analysis of 
Clay Minerals 2nd ed., New York : Oxford University Press.

Peltonen, C. et al., 2009. Clay mineral diagenesis and quartz cementation in mudstones: The effects of smectite to illite reaction on rock properties. Marine and Petroleum Geology $26(6), 887-898$.

Potter, P.E., Maynard, J.B. \& Depetris, P.J., 2005. Mud \& Mudstones: Introduction and overview, Springer Berlin Heidelberg.

Rice, S.B. et al., 1995. Application of fourier transform infrared spectroscopy to silica diagenesis: The opal-A to opal-CT transformation. Journal of Sedimentary Research A65 (4), 639-647.

Roduit, N., 2008. JMICROVISION: Image Analysis Toolbox for Measuring and Quantifying Components of High-definition Images. Available at: http://www.jmicrovision.com.

Ross, D.J.K. \& Bustin, R.M., 2009. Investigating the use of sedimentary geochemical proxies for paleoenvironment interpretation of thermally mature organic-rich strata: Examples from the Devonian-Mississippian shales, Western Canadian Sedimentary Basin. Chemical Geology 260 (1-2), 1-19.

Rutter, E.H., 1983. Pressure solution in nature, theory and experiment. Journal of the Geological Society 140 (5), 725-740.

Sawyer, D.S., Buffler, R.T. \& Pilger Jr., R.H., 1991. The crust under the Gulf of Mexico Basin. In A. Salvador, ed. The Gulf of Mexico Basin. Geological Society of America, Geology of North America, 53-72.

Schieber, J., Krinsley, D. \& Riciputi, L., 2000. Diagenetic origin of quartz silt in mudstones and implications for silica cycling. Nature 406 (6799), 981-5.

Smith, C.N. \& Malicse, A., 2010. Rapid Handheld X-Ray Flourescence (HHXRF) Analysis of Gas Shales. In AAPG Search and Discovery Article \#90108C2010. 
Spain, D.R. \& Anderson, G.A., 2010. Controls on Reservoir Quality and Productivity in the Haynesville Shale, Northwestern Gulf of Mexico Basin. Gulf Coast Association of Geological Societies Transactions 60, 657-668.

Spötl, C., Houseknecht, D.W. \& Riciputi, L.R., 2000. High-temperature quartz cement and the role of stylolites in a deep gas reservoir, Spiro Sandstone, Arkoma Basin. In R. H. Worden \& S. Morad, eds. Quartz Cementation in Sandstones. International Association of Sedimentologists, 281-297.

Thyberg, B. et al., 2010. Quartz cementation in Late Cretaceous mudstones, northern North Sea: Changes in rock properties due to dissolution of smectite and precipitation of micro-quartz crystals. Marine and Petroleum Geology 27 (8), 1752-1764.

Thyberg, B. \& Jahren, J., 2011. Quartz cementation in mudstones: sheet-like quartz cement from clay mineral reactions during burial. Petroleum Geoscience 17 (1), 53-63.

Torsch, W.C., 2012. (Thesis), Thermal and pore pressure history of the Haynesville Shale in North Louisiana: A numerical study of hydrocarbon generation, overpressure, and natural hydraulic fractures. Louisiana State University and Agricultural and Mechanical College.

Turner, P. et al., 1995. Burial history of the Penrith Sandstone (Lower Permian) deduced from the combined study of fluid inclusion and palaeomagnetic data. In P. Turner \& A. Turner, eds. Geological Society, London, Special Publication 98, 43-78.

Vagle, G.B., Hurst, A. \& Dypvik, H., 1994. Origin of quartz cements in some sandstones from the Jurassic of the Inner Moray Firth (UK). Sedimentology 41 (2), 363-377.

Wang, F.P., Hammes, U. \& Li, Q., 2013. Overview of Haynesville Shale properties and production. In U. Hammes \& J. F. W. Gale, eds. Geology of the Haynesville Gas Shale in East Texas and West Louisiana. AAPG Memoir 105, 155-177. 
Weibel, R., 1999. Effects of Burial on the Clay Assemblages in the Triassic Skagerrak Formation, Denmark. Clay Minerals 34 (4), 619-635.

Weyl, P.K., 1959. Pressure solution and the force of crystallization: a phenomenological theory. Journal of Geophysical Research 64 (11), 2001-2025.

Williams, K.E., 2013. Burial History Modeling and Paleogeomechanics of the Barnett and Haynesville. In AAPG 2013 Annual Convention and Exhibition, Pittsburgh, Pennsylvania. p. 5.

Wilson, M.J., Shaldybin, M. V \& Wilson, L., 2016. Clay mineralogy and unconventional hydrocarbon shale reservoirs in the USA. I. Occurrence and interpretation of mixedlayer R3 ordered illite/smectite. Earth-Science Reviews 158, 31-50.

Worden, R.H. \& Burley, S.D., 2003. Sandstone Diagenesis: The Evolution of Sand to Stone. In Sandstone Diagenesis. Blackwell Publishing Ltd., 1-44.

Worden, R.H., French, M.W. \& Mariani, E., 2012. Amorphous silica nanofilms result in growth of misoriented microcrystalline quartz cement maintaining porosity in deeply buried sandstones. Geology 40 (2), 179-182.

Worden, R.H. \& Morad, S., 2000. Quartz Cementation in Oil Field Sandstones: A Review of the Key Controversies. In R. H. Worden \& S. Morad, eds. Quartz Cementation in Sandstones. 1-20.

Wright, A.M., Ratcliffe, K.T. \& Spain, D., 2010. Application of Inorganic Whole Rock Geochemistry to Shale Resource Plays. In Canadian Unconventional Resources \& International Petroleum Conference. 19-21. 


\section{FIGURE CAPTIONS}

Figure 1. Geological background of the Haynesville-Bossier Shale. (A) General location of Haynesville-Bossier in Texas and Louisiana. (B) Paleogeographic map at the time of Haynesville deposition (after Hammes, 2011) with core locations indicated. (C) Chronostratigraphic chart of Haynesville-Bossier (after Cicero et al., 2010). Red bars denote the approximate temporal and geographic locations of the three wells in this study. (D) 1D burial history model (after Williams, 2013). BSR: Bossier, HVL: Haynesville, T: Tertiary.

Figure 2. Haynesville-Bossier facies microfacies and grain size data. (A) Fine mudstone (fMs) sample number 7. (B) Medium mudstone (mMs) sample number 8 . (C) Coarse mudstone (cMs) sample number 5. (D) Sandy mudstone (sMs) sample number 3. (E) Cumulative frequency plot of maximum measured grain lengths ( 200 measurements per sample) from nine representative samples. (F) Ternary diagram of grain size for nine representative samples. Ternary diagram based on Lazar et al. (2015).

Figure 3. Overlain X-ray diffractograms of clay separate and glycolated clay separate. 001 peak sharpening (green line) at $8.9^{\circ} 2 \theta(10.1 \AA ̊)$ indicates the presence of illite-smectite.

Figure 4. Quartz grain replacement. (A) BSE SEM Quartz cement replacing calcite in gastropod. (B) BSE SEM image of quartz pyrite and chlorite cement within gastropod. Pyrite framboid development appears to have occurred first, followed by the development of chlorite (possibly through a kaolinite precursor) within the open chamber of the gastropod. Quartz appears to have then replaced most of the calcite chamber walls. (C) Unidentifiable carbonate bioclast partially replaced by dolomite, pyrite, albite and quartz. (D) Dolomitised bioclast (bivalve?), partially replaced by quartz. qtz = quartz, cal = calcite, py = pyrite, $c h l=$ chlorite, alb = albite, dol = dolomite 
Figure 5. BSE images of numerous quartz silt grain contacts in coarse mudstone microfacies. Small white arrows indicate locations where grain contacts occur, discontinuities between grain contacts are approximately perpendicular to orientation of arrows. qtz = quartz.

Figure 6. BSE images of quartz cement in the range of microfacies. Small white arrows indicate locations where grain contacts occur, discontinuities between grain contacts are approximately perpendicular to orientation of arrows. (A) Elongate quartz grain. (B) Mica grain trapped at grain discontinuities. (C) Pyrite trapped at grain discontinuity. (D) Pyrite trapped at grain discontinuity. (E) Mica grain within quartz grain in microfacies with low silt content. (F) Mica grain within quartz grain in microfacies with low silt content. Possible grain contact is marked by small white arrows. $q \mathrm{qtz}=$ quartz, $\mathrm{cal}=$ calcite, $\mathrm{py}=$ pyrite, mic $=$ mica.

Figure 7. BSE and SEM-CL images of quartz cement. (A) SME-CL image of detrital quartz grains (lower luminescence) and quartz cement (higher luminescence) (B) BSE image with outline of detrital quartz grains overlain (medium grey) and quartz cement (medium grey); a subsequent dolomite cement is visible in the centre of the image (light grey). (C) SME-CL image of detrital quartz grains (lower luminescence) and quartz cement (higher luminescence) (D) BSE image with outline of detrital quartz grains overlain (medium grey) and quartz cement (medium grey); a subsequent dolomite cement is visible in the centre of the image (light grey). (C) SEM-CL image of a silt-rich sample. Higher luminescence detrital quartz and authigenic dolomite grains have a perimeter of lower luminescence quartz overgrowth. (D) BSE SEM image of E. (E) SEM-CL image of a silt-rich sample. Five higher luminescence quartz grains have a perimeter of lower luminescent quartz overgrowths. The two detrital quartz grains in the centre and upper left of the image appear to demonstrate a grain contact. This contact could indicate pressure solution is one source of silica particularly 
in the silt-rich microfacies. (F) BSE SEM image of E. (G) SEM-CL image of a silt-poor sample. Higher luminescent detrital quartz grains have a perimeter of lower luminescent quartz overgrowth. (H) BSE SEM image of G. Quartz over growth is indicated. qtz = quartz, qtz ovg = quartz overgrowth, alb = albite, dol = dolomite, $\mathrm{Fe}$-dol = iron dolomite.

Figure 8. Quartz grains and apparent quartz cement intergrown or encased within carbonate cement. (A) Euhedral grain boundaries between quartz and dolomite cements. (B) Quartz grains with elongate and lobate morphologies encased in partially dolomitised calcite qtz $=$ quartz, cal $=$ calcite, dol $=$ dolomite,$p y=$ pyrite .

Figure 9. Zirconium (ppm) and silica (\%) concentration in studied samples from XRF datasets.

Figure 10. Schematic diagram outlining the development of quartz overgrowths on setrital grain surfaces.

Table 1. Summary quantitative XRD data for the Haynesville and Bossier Formations, with the number of samples analysed $(\mathrm{N})$, minimum, mean and maximum values for each mineral phase. 


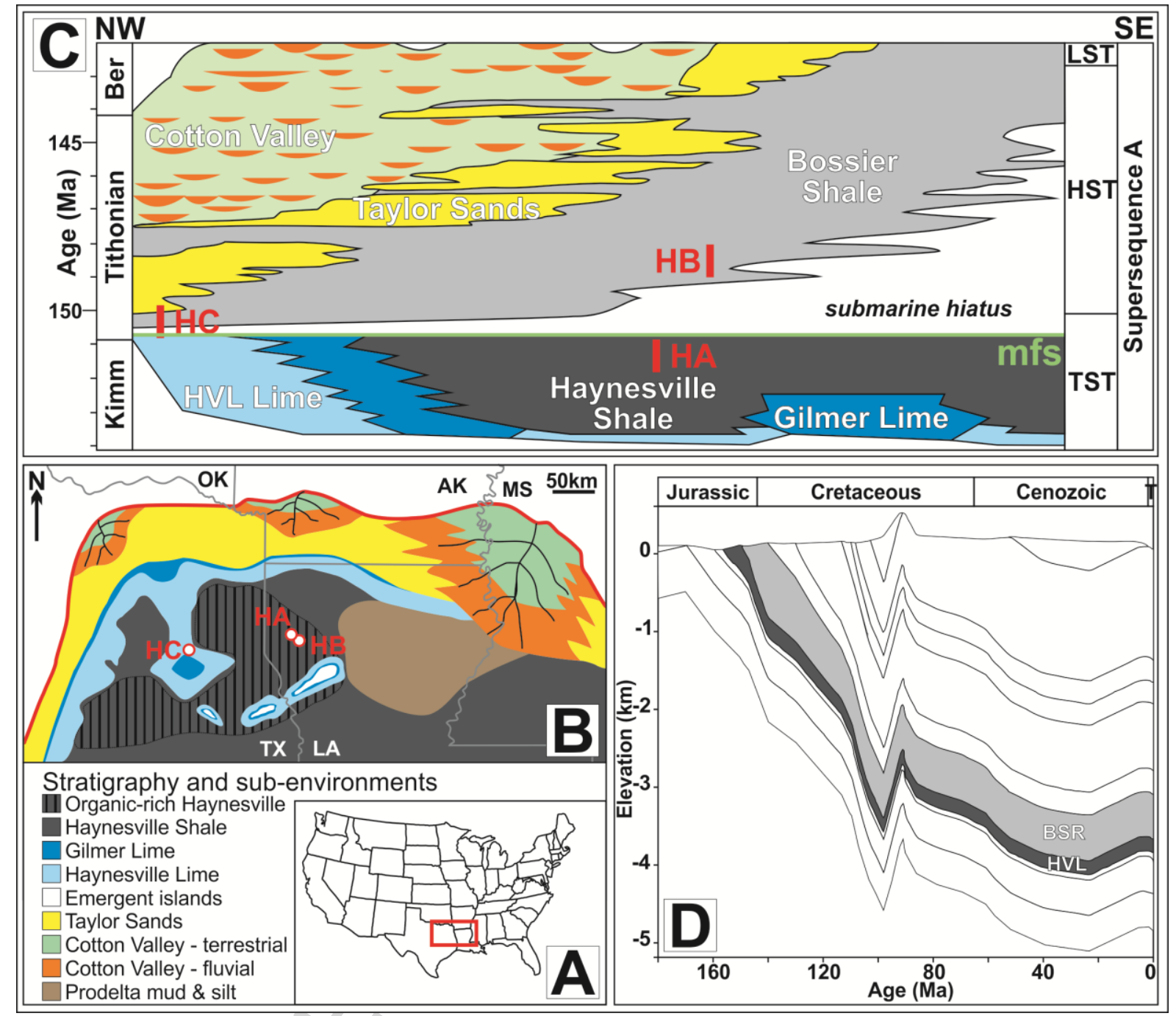

Figure 1 

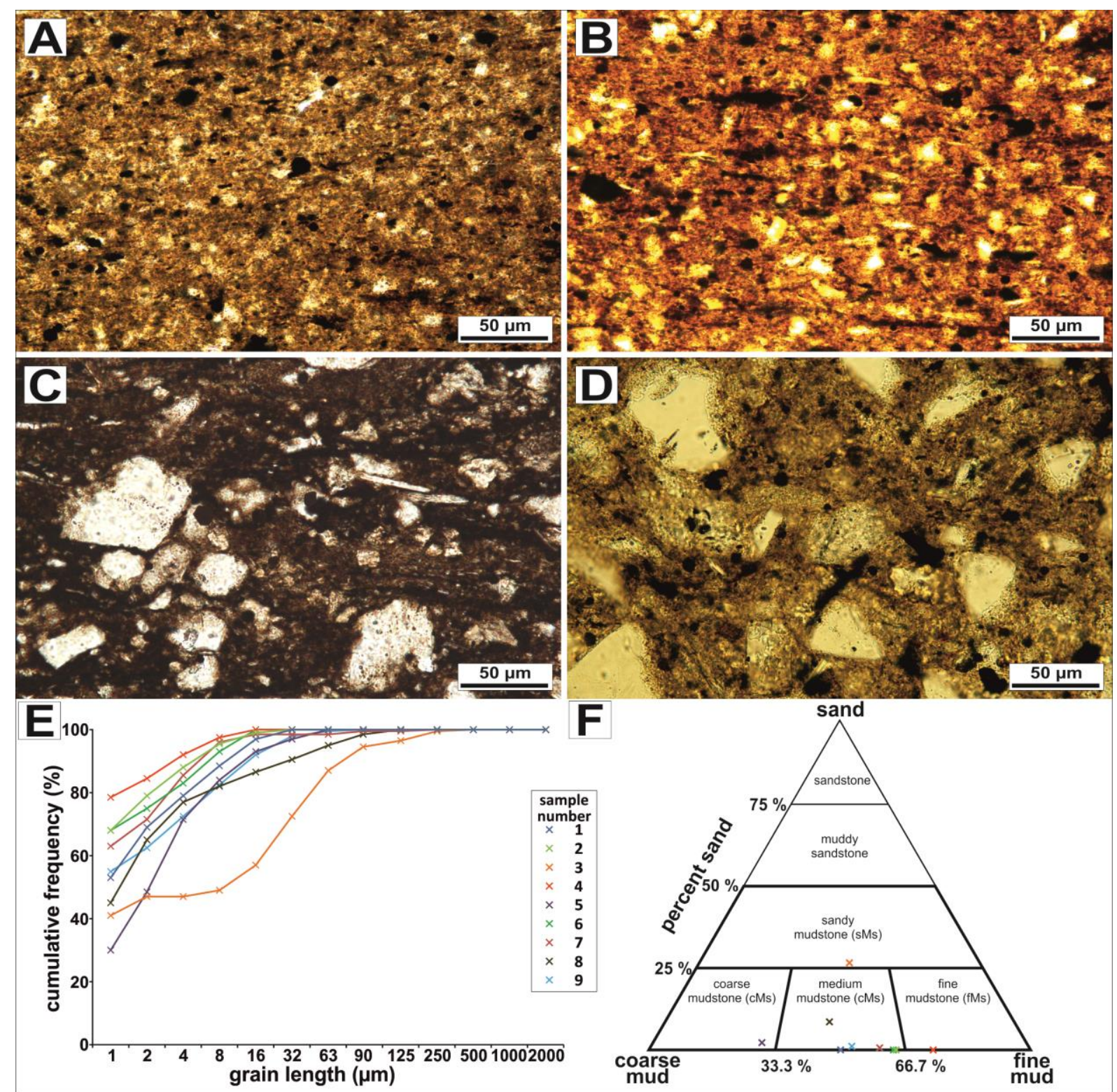

$F$

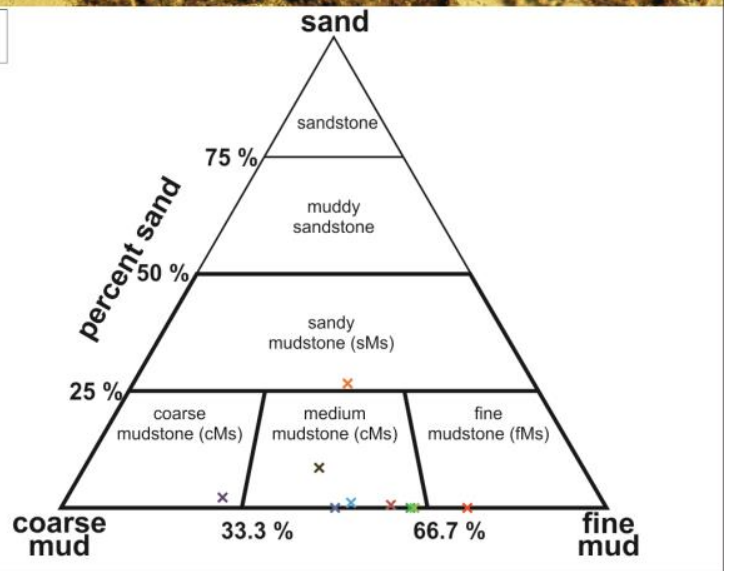

Figure 2 


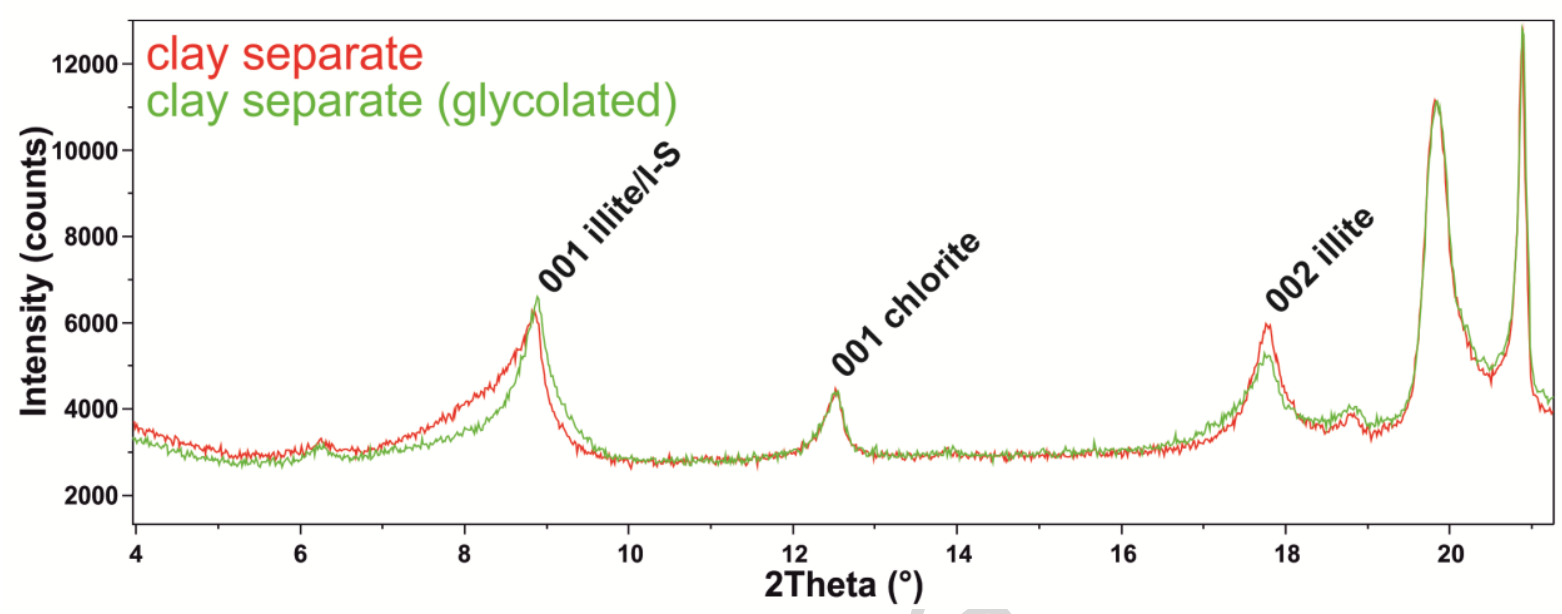

Figure 3 


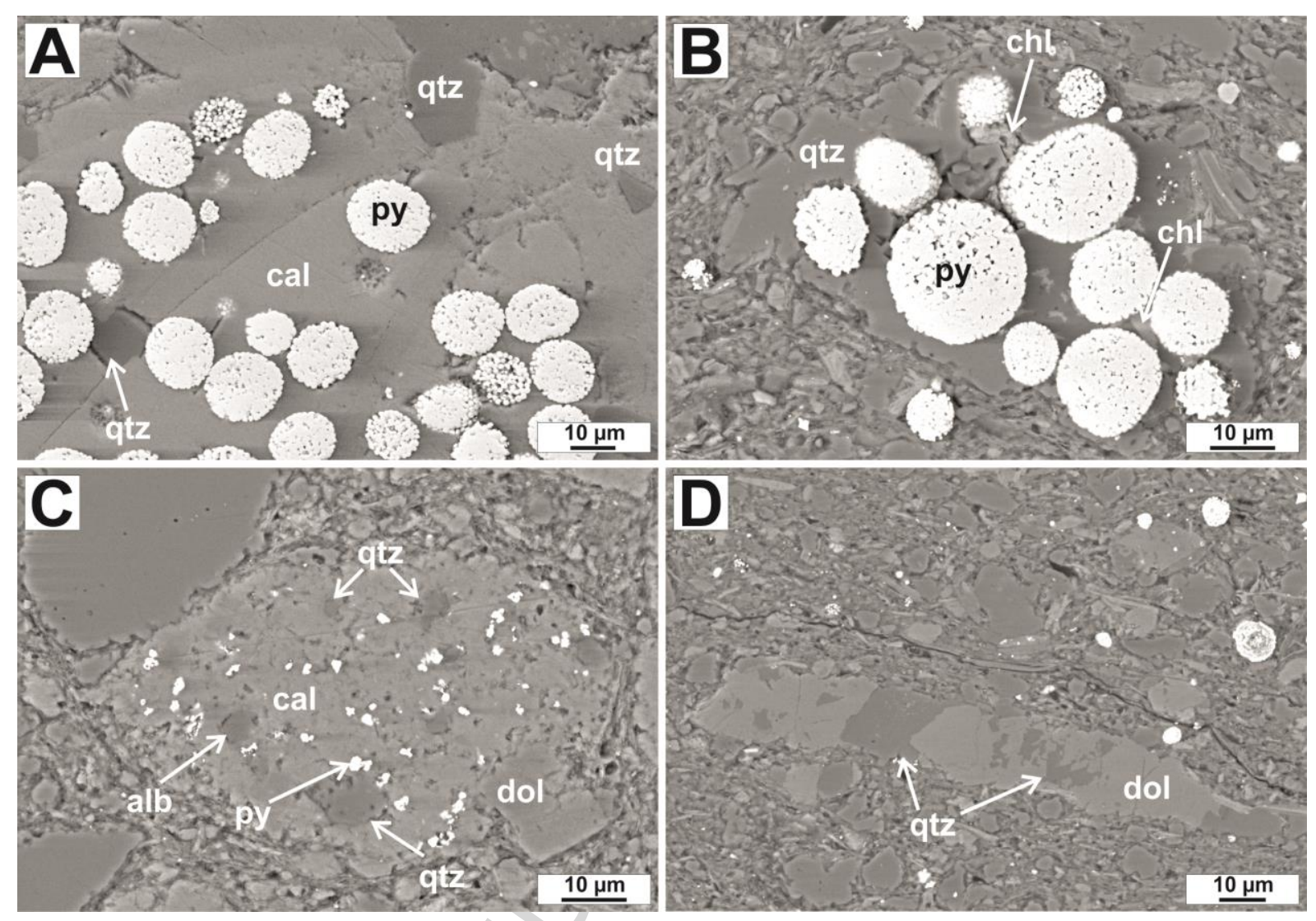

Figure 4 

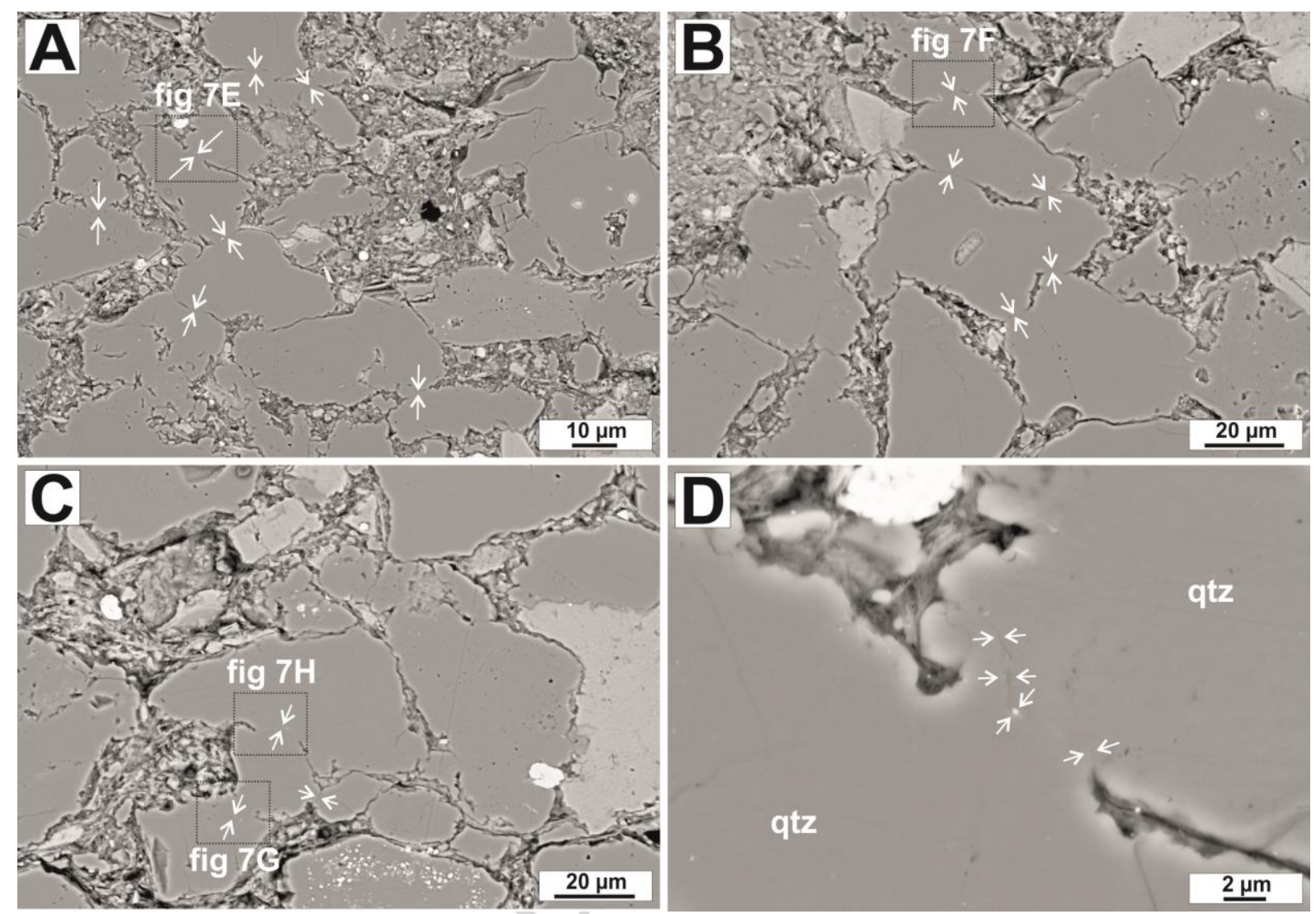

Figure 5 


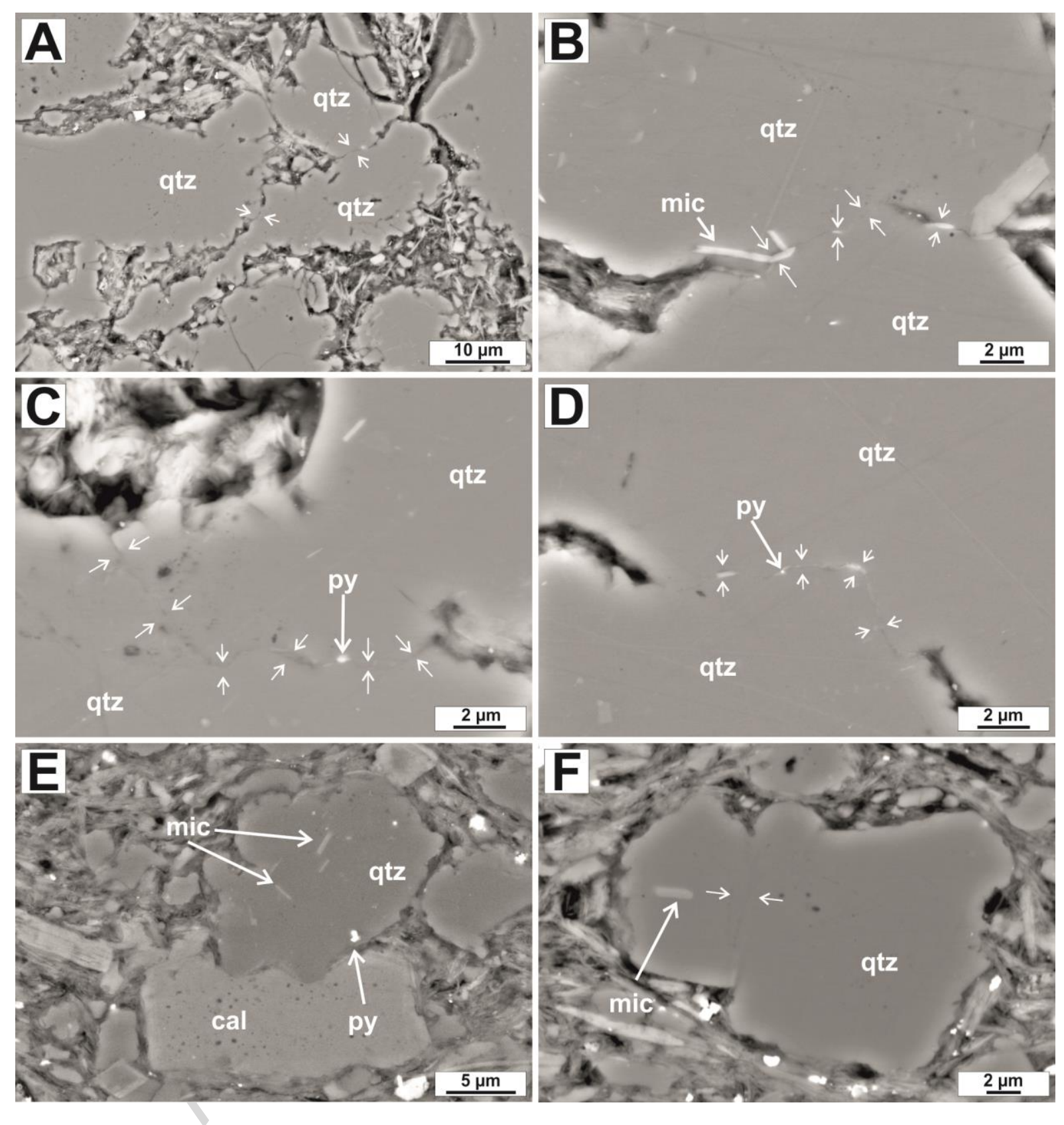

Figure 6 


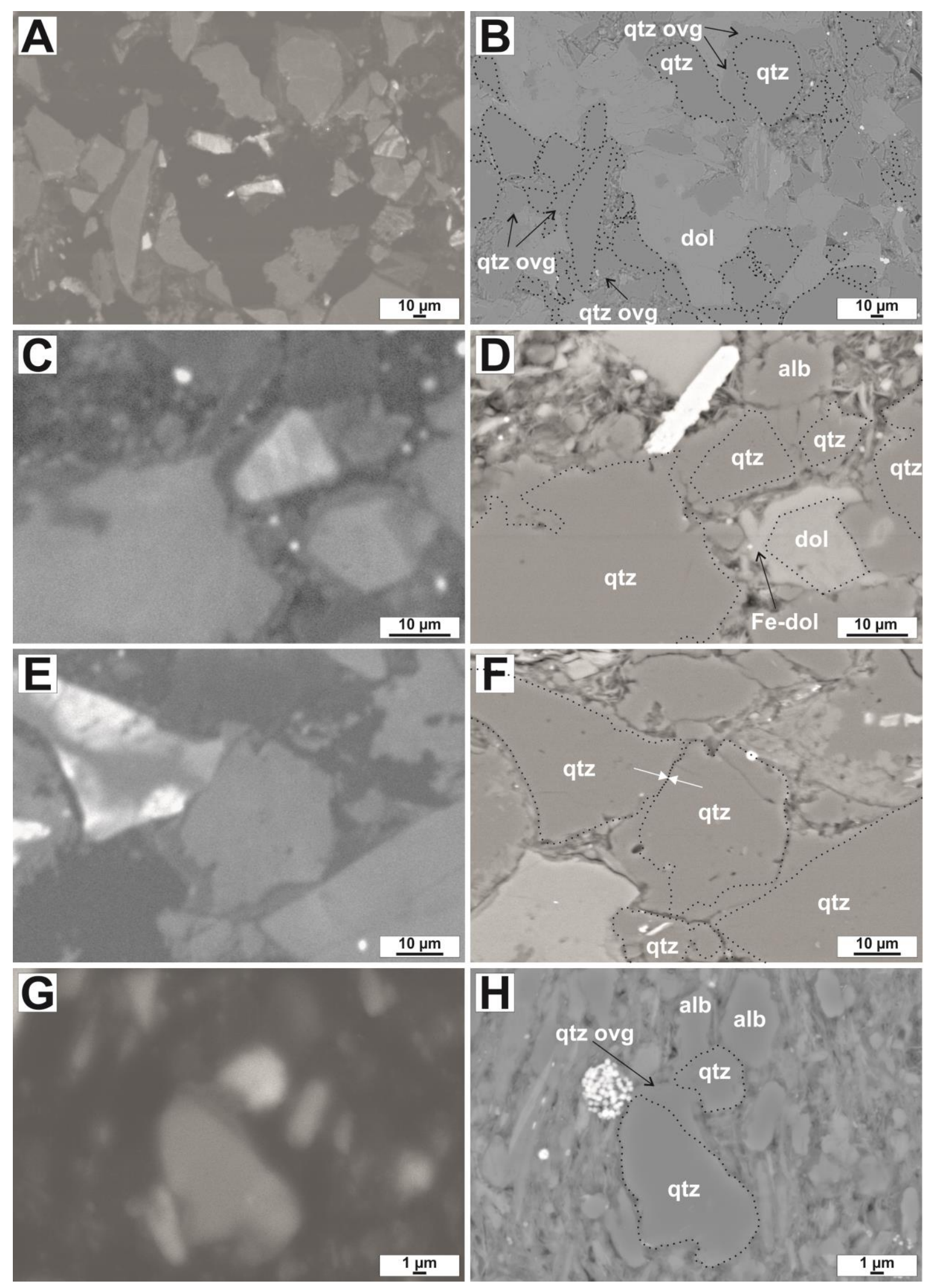

Figure 7 


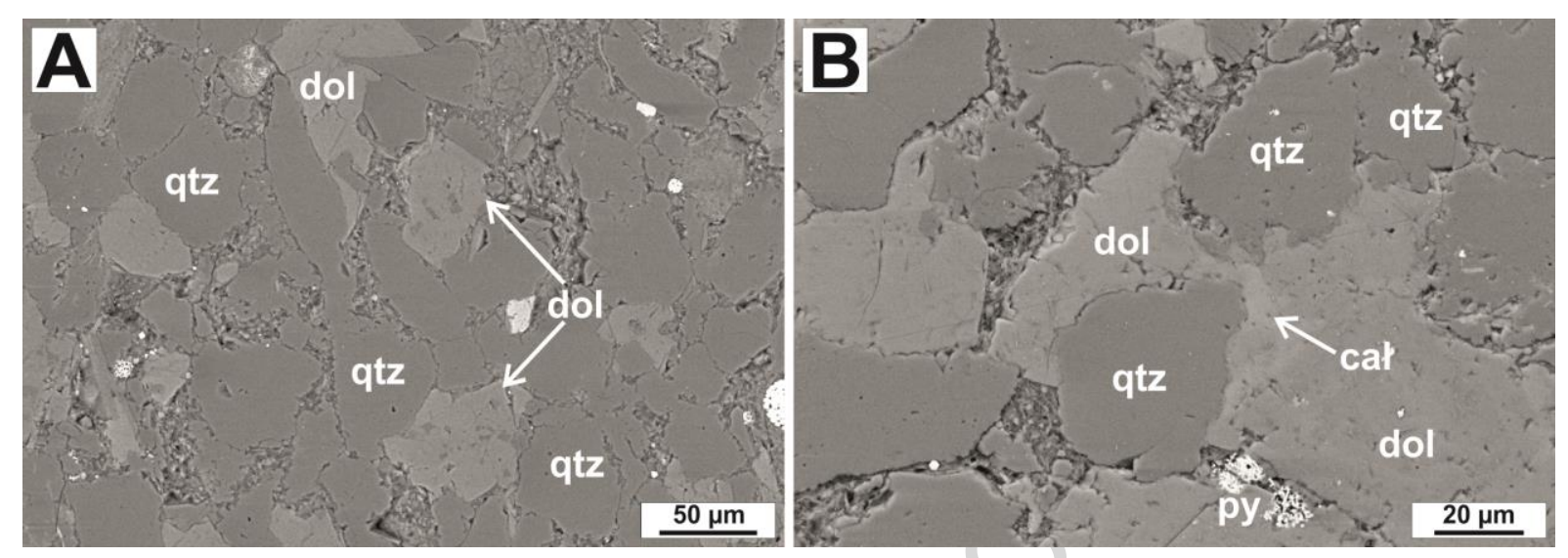

Figure 8 


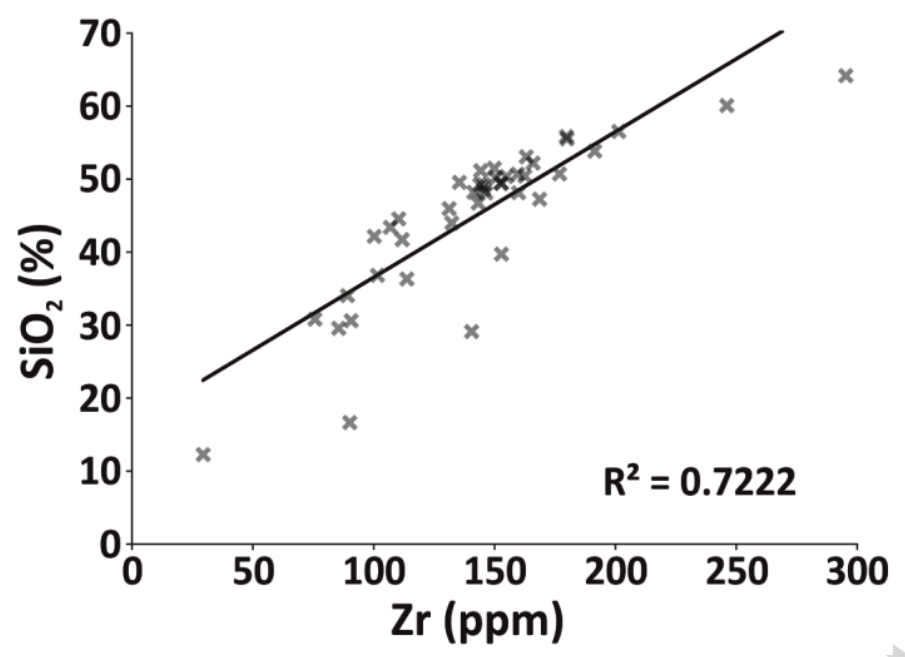

Figure 9 


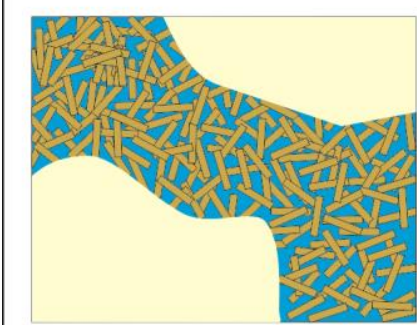

1) Deposition of quartz silt and clay mineral-rich matrix

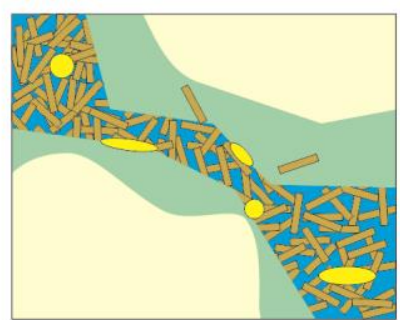

3) Quartz overgrowth development. Pyrite and clay minerals displaced aligning with crystal face. Some grains are engulfed. Most grains are replaced by the overgrowth.

\section{porosity detrital quartz clay mineral matrix}

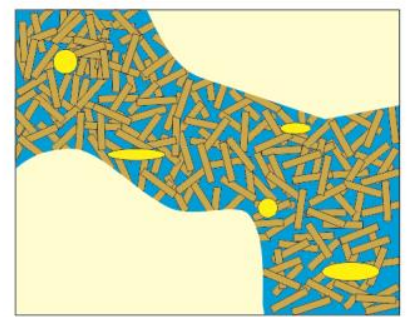

2) Precipitation of pyrite within the matrix

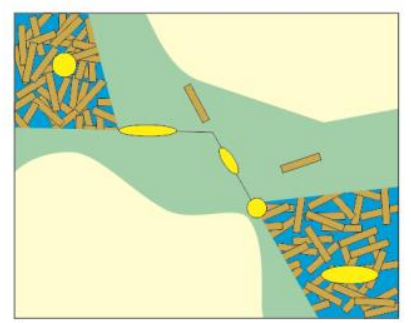

4) Quartz overgrowths continue to develop as quartz crystals intersect. Grains are trapped at the interface between quartz crystals

$\square$ pyrite
$\square$ quartz overgrowth
$\square$ discontinuity

Figure 10 
Table 1

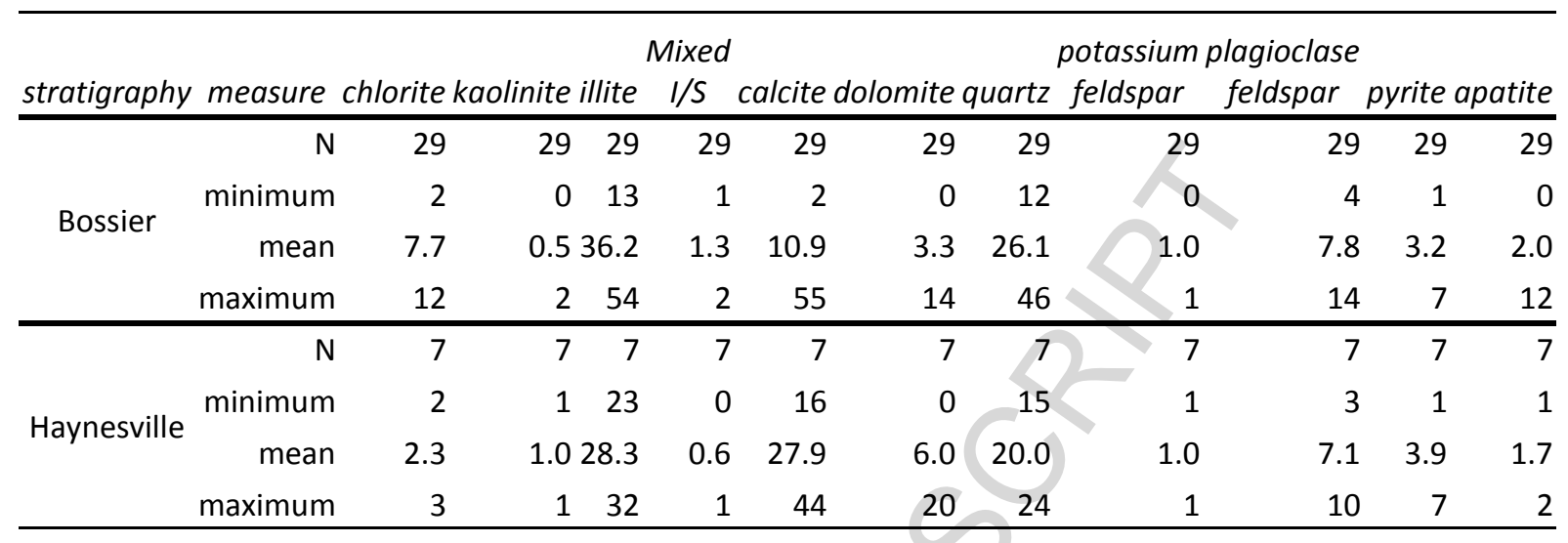


highlights

- Two types of quartz: grain replacement and grain overgrowths.

- Quartz cement is areally significant at up to $13 \%$.

- Petrography shows matrix components (pyrite and mica) within quartz overgrowths.

- Processes of engulfment, displacement and replacement of matrix.

- Pressure solution and smectite to illite transformation supply silica. 